\title{
Bushman Paintings in the Ma-Dobo Range ("Matopos"), Southern Rhodesia
}

\section{Author(s): R. N. Hall}

Source: The Geographical Journal, Vol. 39, No. 6 (Jun., 1912), pp. 592-596

Published by: geographicalj

Stable URL: http://www.jstor.org/stable/1778197

Accessed: 08-05-2016 02:56 UTC

\section{Your use of the JSTOR archive indicates your acceptance of the Terms \& Conditions of Use, available at}

http://about.jstor.org/terms

JSTOR is a not-for-profit service that helps scholars, researchers, and students discover, use, and build upon a wide range of content in a trusted digital archive. We use information technology and tools to increase productivity and facilitate new forms of scholarship. For more information about JSTOR, please contact support@jstor.org.

The Royal Geographical Society (with the Institute of British Geographers), Wiley are collaborating with JSTOR to digitize, preserve and extend access to The Geographical Journal 
though hundreds of pilgrims on their way hither passed through A-tun-tzŭ in the autumn.

Down below we crossed a big snow-drift, and after an extraordinarily steep descent reached the valley in which flowed a big stream, obviously another of the glacier streams from K'a-gur-pu.

This immense triple-peaked massif is situated almost immediately opposite the great snow mountain overhanging T'sam-pu-t'ong, and the two of them correspond in position to the line of junction between the rainy and arid regions of the Mekong and Salween valleys, so that it is evidently these peaks and the northward extension of the two ranges at a great elevation which form the remarkable rain-screen in these regions, whereby the Mekong-Yangtze divide has its rainfall cut off and the snow-line suddenly elevated to something like 19,000 feet.

The descent down this valley was through forest similar to that on the other side; gradually we got down out of the rain, and when we pitched camp for the last time there were stars shining overhead.

At the village of Londre, a little above the Mekong, we were told that two Chinese soldiers had arrived on the previous day in search of us, but instead of crossing to the Salween by the Do-ker La, they had gone over the main pass between the Doker-la and the Sie-la.

That same evening we reached the Mekong after a journey lasting nineteen days. There was an interview with the official when we got back to A-tun-tzŭ two days later, but I believe he was genuinely pleased to see us safely back, though he gave a certain amount of trouble when we returned to the Salween in November.

\title{
BUSHMAN PAINTINGS IN THE MA-DOBO RANGE ("MATOPOS"), SOUTHERN RHODESIA.
}

\author{
By R. N. HALL.
}

HAVING just returned from a six weeks' tramp, with my tent and boys (Makaranga), in the remoter parts of the Ma-Dobo range (incorrectly styled "Matopos"), I fancied the Fellows of the Society might like a few words describing some points of what must prove to be a very valuable and an unique discovery.

Only six caves with paintings were previously known, and but three of these had ever been described and that but partially. These six included the "World's view cave." But it is now evident that the "World's view" paintings are far excelled in the number of objects portrayed, in their variety, in their size as heroic pictures, in the number of different colours introduced in depicting one object, and what is more important, in the higher conception, the greater skill and freedom, and more artistic taste, by the paintings in the majority of the thirty 


$$
\begin{aligned}
& 4 \\
& 14
\end{aligned}
$$


additional caves which $I$ have just discovered and located on my chart of this range.

To these thirty new caves and shelters must be added fully a hundred sets of newly-discovered paintings of the Beispielen order, that is, a few objects only on isolated rocks on the open. Some of these show unique examples of considerable artistic merit; the discovery of Beispielen paintings in any number in any locality point to the existence of a large central cave with paintings being present somewhere in the hills of the vicinity.

The enormous size of the animals-elephants, giraffes, rhinoceroses, lions, antelopes, and snakes,-is astonishing, some being as much as 8 feet and 10 feet wide and long, and not a few of them are painted high up in the concave roofs of the caves. It is relatively easy to paint an animal correctly in miniature, but it is a test of artistic skill to produce such in heroic size, and yet show muscle, tendon, and pose, and an absolutely correct outline, true to form, habit and movement. A shoal of seven large fishes is ideal. Snakes are numerous, and all have giraffe-shaped heads, and vary in size from 3 feet to 15 feet in length. Several have humps along their backs on which are painted baboons, buck, men, and what must be mythological creatures. Four colours are introduced into one large snake-red, white, yellow, and purple, while in a nother are five colours-purple, yellow, red, brown, and black.

A white giraffe, 3 feet long, has yellow triangular patches on its body, and a red mane, while other giraffes show patches in red. A giraffe running is exceedingly natural. Several buck in red have white necks and breasts, and ostriches have white wing and tail feathers. Storks and other birds have white necks and bodies, but black wings. Some birds are quite white, others pink and white. A bird sitting on a branch exactly resembles a robin on a Christmas card. Baboons are shown walking, climbing, jumping from bough to bough, and drinking.

The trees portrayed include knobby thorns, baobabs, umbrella trees, palrus, tree-ferns, euphorbias, kafir orange, aloes, wind-blown trees, and monkey ropes, as well as aerial and exposed roots. Plant-life is general and lovely. There are flowers, flowering shrubs, some bi-coloured, also different grasses. The plants are numerous, and Mr. Dowsett, the curator of the Matopo Park and Nursery, states that some of the trees and plants are African, but not Zambezian. One plant, in a Beispielen set of paintings, has each of its six fronds of a different form, and is artistically conceived and portrayed.

The human form, in every attitude, and showing all forms of action, is very general, and is mainly scenic. All the original portrayals of men and women show the nude, but in the men there is nothing objectionable presented. The elongation of the human figure and the too natural male do not appear except in the work of later painters, who have covered over some of the original designs with less artistic drawings. A 
man fishing, another with a noose, a man carrying a small buck, one up a tree shooting, a group standing round a slain buck (two examples), a man walking hand-in-hand with a woman (very gracefully depicted), archers with very long bows, groups of men sitting and-reclining round fires, several mothers nursing children, also children crawling near parents, maidens dancing, dances of men, dances of men and women, many processions of men, and four examples of human spoor, right and left foot, standing, walking, and running.

Some caves contain hundreds of painted objects, but in none is there any representation of any Bantu object. These only appear scrawled over the paintings with pointed ends of charred sticks, and are the work of relatively late Bantu. The shining, jet black manlis (Kafir-god), and the concentric ring pattern, both forms common in Mashonaland paintings, are also in evidence in several of the Ma-Dobo paintings.

One feature of my new discoveries is the number of representations of the Victoria falls (one 6 feet $\times 4$ feet). Of these four were met with; these making, with similar representations in caves I discovered in Mashonaland, a total of seven, while two others have been lately reported to me, making nine examples. The finest specimen shows streams of white water falling over red cliffs, the sides of the Devil's cauldron, and a pillar of spray rising from the foot of the falls to 2 feet higher than the top, and blowing off to the west.

But the gem of these discoveries was three carved snakes, with giraffe heads (as in the paintings). These snakes are on a flat rock near a cave with paintings. One is 6 feet long and the others 3 feet, and each is slightly incised in the rock throughout its entire length and width. Further, a painted giraffe and some buck discovered had their outlines incontinuously incised, not in single strips, in the rock before being painted, as also the line of vertical strokes representing their manes. This association of Bushman sculptor and Bushman painter points, I believe, to the identity of both as one people and of one period, a belief I have always held, though all painters were not sculptors.

These recently discovered paintings are undoubtedly important, and in every way they exceed in artistic skill anything portrayed, whether in Dr. Theal's collection, or those of the late Mr. Slow, the Misses Bleek and Tonge, or the South African Museum. I made about 250 tracings which I. coloured on the spot to the tone of the originals, and these, with numerous photographs, constitute a unique Bushman National Gallery.

These notes are but preliminary to a fuller report I shall make to the Rhodesian Scientific Association after I have completed a second systematic search in the Ma-Dobo.

Including the Ma-Dobo caves and also the caves in Mashonaland and Matebeleland, the number of important sets of paintings on my register number a little over 300, while those of the Beispielen order, so far discovered, nearly exceed that number. This is evidence that the name of 


\begin{abstract}
Wak Wak given by Massonde, Edrisi, and other Arabian and Persian writers of the tenth to the twelfth century, to the region of our goldfields, was well justified, as was also the name Abutwa ("the land of the little men"), which these territories have been called by the Bantu since some traditional time prior to 1485 , and which latter name still appears on the most recent and all the present maps of Southern Rhodesia.
\end{abstract}

\title{
ENVIRONMENT IN TURKEY AND JAPAN.*
}

THE two papers noted below are both by Prof. Ellsworth Huntington, of Yale University, a geographer hardly surpassed by any for the numerous new ideas entitled to serious attention to which he has given rise, or for the fascination with which they are set forth. Prof. Huntington, though, as is well shown by one of those papers, possessed of a mind as hospitable to the ideas of others as prolific of his own, is always himself, so that these two papers are in every respect typical of his work. They both show the same spirit of eager research, the same directness, the same ingenuity, but here and there something of the same tendency to be hurried along by the sweep of a broad generalization. The general drift of both is well illustrated by a remark made in that on Japanese character. Speaking of Buckle's theory, he says that in a nutshell, "it was that physical environment determines the character and achievements of all the races of the world, and that climate is the most important of all the elements of physical environment," and that to dismiss this theory "as a "blanket theory' unworthy of further study is as unscientific as to accept it without proof" (pp. 271-2). Formally, no objection can be taken to Prof. Huntington's observation. Moreover, no geographer will call in question the great influence of physical environment on human achievement, or the high importance of climate among the elements of physical environment, yet it may well be doubted whether cautious geographers are not right, after due study, in rejecting Buckle's theory as a " blanket theory," and whether Prof. Huntington, in spite of his painstaking habit of mind, does not allow his leaning to this theory to carry him too far. For instance, in referring to the general slackness and backwardness of the tropical races as compared with those of the temperate zone, he states, following Ireland, that from the tropics no man, except Mohammed, has ever arisen who has the least claim to a place among the world's leaders, and adds that Gautama, the founder of Buddhism, "was born and reared among the Himalayas, almost exactly $30^{\circ}$ north of the equator." Now, apart from the fact that the birthplace of Gautama is placed somewhat too far to the north, that birthplace, instead of being among the Himalayas, was among the rice-swamps of the Tarai, at the foot of the Himalayas, where the chief influence of those mountains is to allow of a moist and uniformly hot tropical climate pushing further north than anywhere else on the globe, and the career of Gautama belongs mainly to latitudes considerably further to the south. Moreover, those who are most absolute in their contention of the incompatibility of native civilization with a tropical climate have to account on the one hand for such remarkable monuments as those of Angkor Wat, in Cambodia, and Boro Bodor, in Java, and on the other

* "Physical Environment as a Factor in the present condition of Turkey;" "Geographical Environment and Japanese Character." (Reprinted from the Journal of Race Development, vol. 1, April, 1911, and vol. 2, January, 1912.) 